\title{
Some Properties of Bio-Yogurt Enriched with Cellulose Fiber
}

\author{
Mutlu B. Güler-Akın*, Busra Goncu, M. Serdar Akın \\ Department of Food Engineering, Engineering Faculty, Harran University, Şanlıurfa, Turkey \\ Email: *mutluakin@harran.edu.tr
}

How to cite this paper: Güler-Akın, M.B., Goncu, B. and Serdar Akın, M. (2018) Some Properties of Bio-Yogurt Enriched with Cellulose Fiber. Advances in Microbiology, 8, 54-64.

https://doi.org/10.4236/aim.2018.81005

Received: December 25, 2017

Accepted: January 28, 2018

Published: January 31, 2018

Copyright $\odot 2018$ by authors and Scientific Research Publishing Inc. This work is licensed under the Creative Commons Attribution International License (CC BY 4.0).

http://creativecommons.org/licenses/by/4.0/

(c) (i) Open Access

\begin{abstract}
In this study, bio-yogurts, which contain L. acidophilus and Bifidobacterium animalis subsp. lactis, were produced with cellulose fiber (CF) addition at a various level $(0 \%, 0.5 \%, 1 \%$ and $2 \%)$ and stored at $4^{\circ} \mathrm{C} \pm 1^{\circ} \mathrm{C}$ for 20 days. Bio-yogurts were analysed 1,10 and 20 days after production. The storage period significantly influenced overall properties of the samples. Addition of CF has positively affected the physical and textural properties of yoghurt, such as serum separation, water holding capacity, viscosity, firmness, adhesiveness, cohesiveness, springiness, gumminess and chewiness $(p<0.05)$. It also slightly stimulated the development of probiotic bacteria $(p<0.05)$. Bio-yogurt, which contains $0.5 \% \mathrm{CF}$ in sensory aspect, is the most appreciated.
\end{abstract}

\section{Keywords}

Bio-Yogurt, Cellulose Fiber, Prebiotic Effect, Yogurt Quality

\section{Introduction}

Due to their attributed health benefits, probiotic bacteria (such as L. acidophilus and/or Bifidobacteria) have been increasingly included in yogurts and fermented milks during the past three decades. The addition of probiotic bacteria is made not only because of certain claimed health-promoting effects in the intestinal tract but also because of the sensory aspects as well as the expanding variety of products that can be formulated with them [1].

In order to produce therapeutic benefits, a suggested minimum level for probiotic bacteria in fermented milk is from $10^{6}$ to $10^{7} \mathrm{cfu} \cdot \mathrm{mL}^{-1}$ [2]. However, these organisms often show poor viability in market preparations [3] [4] [5]. Therefore, manufacturers were interested in developing a process that can provide high densities of the probiotic strains in the product. Prebiotics, such as oligo- 
saccharides are added to food mainly to allow the preferential growth of probiotic organisms [6].

Dietary fiber (DF) is a remnant of the edible part of plant; it is analogous carbohydrates that are resistant to digestion and absorption in the human small intestine and undergo complete or partial fermentation in the human large intestine. DF includes oligosaccharides, lignin, resistant starch, tannins and associated plant substances [7] [8].

Cellulose, the earth's most abundant natural material, is a long-chain carbohydrate polymer of repeating glucose units. Cellulose has $\beta$-glycosidic linkages, which cannot degrade human carbohydrate digestive enzymes and is widely accepted as a dietary fiber [9]. Many dietary fibers have been shown to offer potential health benefits to the gastrointestinal tract [10]. CF is indigestible in the upper gastrointestinal tract (GIT) but partially fermentable in the colon [11] and so may potentially have limited use as a prebiotic in functional food.

The aim of this study was to determine the prebiotic effect of CF on the $L$. acidophilus and Bifidobacterium BB-12 and the effect of addition of CF on the overall quality of bio-yogurt.

\section{Materials and Methods}

\subsection{Materials}

Cow's milk (morning milking) used in the manufacture of bio-yogurt was collected two times during March 2017 in Şanlıurfa in southeastern Turkey. The milks were inoculated with ABT3 culture consisting of Streptococcus thermophilus, Lactobacillus acidophilus and Bifidobacterium animalis subsp. lactis (BB12), which was obtained from Peyma-Chr. Hansen (Turkey).

\subsection{Preparation of Culture}

Reconstituted skim milk, with $12 \%$ dry matter, was prepared and sterilized at $105^{\circ} \mathrm{C} \pm 1{ }^{\circ} \mathrm{C}$ for $3 \mathrm{~min}$. Then it was cooled to $40^{\circ} \mathrm{C}$ and inoculated with ABT3 culture, using a $0.05 \%(\mathrm{w} / \mathrm{v})$ inoculums. The cultures were grown for $4 \mathrm{~h}$ at $37^{\circ} \mathrm{C}$. The milk was kept cooled at $4^{\circ} \mathrm{C}$ until for $8 \mathrm{~h}$, before using yogurt production.

\subsection{Production of Bio-Yogurt}

Manufacture of yogurts was achieved according to Tamime and Robinson [12]. Two different trials were performed for the manufacture of bio-yogurt. On each trial, the large flocs were removed from raw cow's milk by using a cloth filter and divided into four equal portions (each 5 litres). The first (A) batch was control, the second (B), third (C) and fourt (D) batches were fortified with CF at a rate of $0.5 \%, 1 \%$ and $2 \%$, respectively. After addition of skimmed milk powder $(3 \% \mathrm{w} / \mathrm{w})$ each milk was heat-treated at $90^{\circ} \mathrm{C}$ for $10 \mathrm{~min}$, cooled to $45^{\circ} \mathrm{C}$, inoculated with ABT3 culture at a rate of $5 \%$ and dispensed into plastic cups $(200 \mathrm{ml})$. All batches were incubated at $40^{\circ} \mathrm{C}$ until pH 4.6. Then they were transferred to a cold store $\left(4^{\circ} \mathrm{C} \pm 1^{\circ} \mathrm{C}\right)$ immediately. 


\subsection{Analytical Methods}

The $\mathrm{pH}$ of the milk and bio-yogurt was measured using a digital $\mathrm{pH}$-meter and titratable acidity was determined according to the Soxhlet-Henkel method [13]. The protein, moisture and ash contents of milk, yogurt and bio-yogurt were estimated from the crude nitrogen content of the samples determined by the Kjeldahl, oven-drying and gravimetric methods, respectively [14]. The total fat contents of milk and bio-yogurt samples were determined by the Gerber method [13]. Whey separation and water holding capacity of the samples were determined by the method described by Kessler and Kammerlahner [15] and Goncu et al. [16], respectively. The viscosity of bio-yoghurts were determined at $4^{\circ} \mathrm{C}$ using a digital Brookfield Viscometer, Model DV-II (Brookfield Engineering Labrotories, Stoughton, MA, USA) [17].

The textural properties of bio-yogurt were evaluated by the textural profile analysis (TPA) method [18]. TPA was performed on cheese samples using a double compression test (TA-XT2i Texture Analyzer; Stable Micro Systems, NY, USA) on $75 \mathrm{~g}$ packed samples. As yogurt presents a pseudoplastic behavior and exhibits partial thixotropy, firmness was measured as the force required to break the structure formed after the cessation of stirring and during the cold storage of the yoghurt. Conditions were as follows: a cylindrical probe (5 $\mathrm{mm}$ in diameter) was inserted to a depth of $15 \mathrm{~mm}$ into the sample at a speed of $1 \mathrm{~mm} \cdot \mathrm{s}^{-1}$. A 1-byte penetration test was applied using a $25-\mathrm{kg}$ load cell. Data collection and calculation were carried out using the Texture Expert Exceed Version 2 V3. The results were expressed as the average of three measurements.

Bio-yogurt samples $(10 \mathrm{~g})$ were decimally diluted in $100 \mathrm{~mL}$ sterile peptone water $(0.1 \%)$ and $1 \mathrm{~mL}$ aliquot dilutions were poured onto plates of the various selective and differential agars in triplicate. M17 agar was used for the enumeration of S. thermophilus [19]. L. acidophilus and Bifidobacterium BB-12 were incubated by using MRS with sorbitol agar and MRS-NNLP agar [20], respectively. All plates were incubated at $37^{\circ} \mathrm{C}$ for $72 \mathrm{~h}$. M17 was incubated aerobically, whereas all other media plates were incubated anaerobically. Anaerobic conditions were created using Anaerocult A sachets (Merck). Plates containing 20 200 colonies were counted and the results are expressed as colony-forming units per gram $\left(\mathrm{cfu} \cdot \mathrm{g}^{-1}\right)$ of sample.

The samples were organoleptically assessed by ten panelists using a sensory rating scale of 1 - 10 for flavour and taste, and 1 - 5 for consistency and appearance as described by Bodyfelt et al. [21]. The panel of assessors was an external panel of non-smokers who were very familiar with fermented dairy products and were selected on the basis of sensory acuity and consistency.

The experiment was designed according to a $4 \times 3 \times 2$ (yogurt type $\times$ storage period $\times$ replication) factorial design. Statistical analysis of data via one-way analysis of variance (ANOVA) was performed to check the significance of differences at $p<0.05$ using SPSS Version 5.0 (SPSS Inc. Chicago, IL, USA). Statistically different groups were determined by the Tukey test [22]. 


\section{Results and Discussions}

\subsection{Bacterial Counts}

Viable bacterial counts of bio-yogurt samples during storage are shown in Table 1. S. thermophilus counts were higher in the samples with CF the control. This could be due to the stimulated growth of Streptococcus species by CF. $S$. thermophilus counts slightly increased with increasing the fiber levels $(p<0.05)$. Sendra et al. [23] and Akin and Akin [24] reported that $S$. thermophilus counts increased in the yogurt supplemented with orange fiber and apple fiber, respectively. The counts of $S$. thermophilus increased slowly during the storage period.

L. acidophilus and Bifidobacterium BB-12 counts of the samples fortified CF were slightly higher than control. L. acidophilus and Bifidobacterium BB-12 counts slowly increased with increasing the fiber levels up to at a rate of $1 \%$, then they reduced. The result of this could be attributed to lower water activity $\left(a_{w}\right)$ of the samples enriched with CF. As known, cellulose had very higroscopic [9] [25] [26]. So the probiotic bacteria couldn't find enough water for growing. During the storage period L. acidophilus and Bifidobacterium BB-12 counts decreased about 1 and $1.8 \log$ cycle, respectively. It could be attributed to acidity of bio-yoghurts. The most important factors affecting the viability of L acidophilus and Bifidobacterium BB-12 are acidity [27]. Acidity of the samples increased during the storage period. At the end of storage, although the viable counts of probiotic bacteria dropped in all bio-yogurts, the counts of $L$. acidophilus were found to be above the threshold for therapeutic minimum $\left(10^{6}-10^{7} \mathrm{cfu} \cdot \mathrm{g}^{-1}\right)$ in all samples. On the other hand, after $10^{\text {th }}$ day of storage the counts of Bifidobacterium BB-12 were found to be under the threshold for therapeutic minimum $\left(10^{6}-10^{7} \mathrm{cfu} \cdot \mathrm{g}^{-1}\right)$ in all samples.

Table 1. The changes of viable bacteria counts of yogurt and bio-yogurt incubated at different temperature during storage period $\left(\log \mathrm{cfu} \cdot \mathrm{g}^{-1}\right)^{\star *}$.

\begin{tabular}{cccccc}
\hline Organisms & $\begin{array}{c}\text { Day of } \\
\text { Storage }\end{array}$ & $\mathrm{A}^{*}$ & $\mathrm{~B}$ & $\mathrm{C}$ & $\mathrm{D}$ \\
\hline & 1 & $8.77 \pm 0.007^{\mathrm{d} 3}$ & $8.93 \pm 0.015^{\mathrm{c} 3}$ & $8.98 \pm 0.146^{\mathrm{b} 3}$ & $9.07 \pm 0.173^{\mathrm{a} 2}$ \\
S. thermophilus & 10 & $8.99 \pm 0.001^{\mathrm{b} 2}$ & $9.02 \pm 0.016^{\mathrm{b} 2}$ & $9.07 \pm 0.024^{\mathrm{a} 2}$ & $9.11 \pm 0.015^{\mathrm{a} 1}$ \\
& 20 & $9.09 \pm 0.056^{\mathrm{a} 1}$ & $9.12 \pm 0.158^{\mathrm{a} 1}$ & $9.13 \pm 0.034^{\mathrm{a} 1}$ & $9.13 \pm 0.121^{\mathrm{a} 1}$ \\
& 1 & $6.97 \pm 0.018^{\mathrm{c} 2}$ & $7.05 \pm 0.029^{\mathrm{a} 2}$ & $7.08 \pm 0.040^{\mathrm{a} 2}$ & $7.02 \pm 0.021^{\mathrm{b} 2}$ \\
L. acidophilus & 10 & $7.30 \pm 0.011^{\mathrm{c} 1}$ & $7.42 \pm 0.005^{\mathrm{b} 1}$ & $7.52 \pm 0.157^{\mathrm{a} 1}$ & $7.25 \pm 0.211^{\mathrm{d} 1}$ \\
& 20 & $6.19 \pm 0.111^{\mathrm{b} 3}$ & $6.31 \pm 0.116^{\mathrm{a} 3}$ & $6.34 \pm 0.147^{\mathrm{a} 3}$ & $6.12 \pm 0.122^{\mathrm{c} 3}$ \\
Bifidobacterium & 1 & $6.99 \pm 0.007^{\mathrm{c} 1}$ & $7.45 \pm 0.06^{\mathrm{a} 1}$ & $7.13 \pm 0.018^{\mathrm{b} 1}$ & $6.95 \pm 0.047^{\mathrm{c} 1}$ \\
BB-12 & 10 & $5.56 \pm 0.443^{\mathrm{c} 2}$ & $5.94 \pm 0.258^{\mathrm{a} 2}$ & $5.66 \pm 0.066^{\mathrm{b} 2}$ & $5.34 \pm 0.035^{\mathrm{d} 2}$ \\
& 20 & $5.26 \pm 0.159^{\mathrm{c} 3}$ & $5.67 \pm 0.147^{\mathrm{a} 3}$ & $5.45 \pm 0.031^{\mathrm{b} 3}$ & $5.25 \pm 0.027^{\mathrm{c} 3}$ \\
\hline
\end{tabular}

A: control, B: $0.5 \%$ CF, C: $1 \%$ CF, D: $2 \%$ CF added bio-yogurts. ${ }^{*}$ Different letters in the same line indicate significant differences among the samples depending on CF level and different numbers in the same column indicate significant differences among the samples depending on storage time $(p<0.05)$. 


\subsection{Physico-Chemical Characteristics}

The chemical composition of milk used for the production of bio-yogurt (data not shown) fell within the following averages: titratable acidity $0.162 \%( \pm 0.06)$ lactic acid, pH $6.7( \pm 0.05)$, total solids $12.95 \%( \pm 0.095)$, fat $3.45 \%( \pm 0.1)$, protein $3.47 \%( \pm 0.115)$, and ash $0.84 \%( \pm 0.005)$.

Some properties of bio-yogurt are shown in Table 2. Addition of CF influenced the $\mathrm{pH}$, titratable acidity, whey separation, water holding capacity and viscosity of bio-yogurt significantly.

The mean level of acidity of the samples supplemented with CF was higher than the control. It could be related the stimulation of bacteria in starter culture by cellulose. Nsor-Atindana et al. [9] reported that microcrystaline cellulose has minimal colonic fermentation. Addition of $\mathrm{CF}$ decreased the $\mathrm{pH}$, while the lactic acid increased. As expected, the storage time significantly affected the level of acidity in the samples. Titratable acidity contents increased, while the $\mathrm{pH}$ decreased during storage.

A negative correlation was determined between whey separation and CF. This result could be related to the water binding capacity of CF. As known cellulose is

Table 2. The changes of some physico-chemical properties of bio-yogurt enriched cellulose fiber $(\mathrm{CF})$ during storage period ${ }^{* *}$.

\begin{tabular}{|c|c|c|c|c|c|}
\hline Properties & $\begin{array}{l}\text { Day of } \\
\text { Storage }\end{array}$ & $A^{*}$ & B & C & $\mathrm{D}$ \\
\hline \multirow{4}{*}{$\mathrm{pH}$} & 1 & $4.66 \pm 0.035^{\mathrm{a} 1}$ & $4.63 \pm 0.070^{\mathrm{a} 1}$ & $4.60 \pm 0.135^{\mathrm{b} 1}$ & $4.53 \pm 0.075^{\mathrm{cl}}$ \\
\hline & 10 & $4.52 \pm 0.055^{\mathrm{a} 2}$ & $4.50 \pm 0.035^{\mathrm{a} 2}$ & $4.48 \pm 0.035^{\mathrm{a} 2}$ & $4.47 \pm 0.035^{\mathrm{b} 2}$ \\
\hline & 20 & $4.48 \pm 0.090^{\mathrm{a} 2}$ & $4.47 \pm 0.015^{\mathrm{b} 2}$ & $4.47 \pm 0.070^{\mathrm{b} 2}$ & $4.31 \pm 0.025^{c 3}$ \\
\hline & 1 & $0.38 \pm 0.006^{\mathrm{c} 2}$ & $0.41 \pm 0.006^{\mathrm{b} 2}$ & $0.41 \pm 0.006^{\mathrm{b} 2}$ & $0.42 \pm 0.002^{\mathrm{a} 2}$ \\
\hline \multirow[t]{3}{*}{$\begin{array}{l}\text { Titratable acidity } \\
\text { (\%Lactic acid) }\end{array}$} & 10 & $0.44 \pm 0.025^{\mathrm{cl}}$ & $0.44 \pm 0.043^{\mathrm{cl}}$ & $0.47 \pm 0.002^{\mathrm{b} 1}$ & $0.49 \pm 0.018^{\mathrm{a} 1}$ \\
\hline & 20 & $0.45 \pm 0.030^{\mathrm{b} 1}$ & $0.45 \pm 0.060^{\mathrm{bl}}$ & $0.48 \pm 0.050^{\mathrm{a} 1}$ & $0.50 \pm 0.080^{\mathrm{a} 1}$ \\
\hline & 1 & $24.29 \pm 0.050^{\mathrm{a} 1}$ & $20.82 \pm 0.215^{\mathrm{b} 1}$ & $18.85 \pm 0.640^{\mathrm{cl}}$ & $17.90 \pm 0.330^{\mathrm{d} 1}$ \\
\hline \multirow[t]{3}{*}{$\begin{array}{l}\text { Whey separation } \\
(\%)\end{array}$} & 10 & $19.88 \pm 0.615^{\mathrm{a} 2}$ & $18.86 \pm 0.590^{\mathrm{b} 2}$ & $18.56 \pm 0.295^{\mathrm{b} 2}$ & $16.84 \pm 0.535^{c 2}$ \\
\hline & 20 & $19.43 \pm 0.420^{\mathrm{a} 3}$ & $18.14 \pm 0.535^{\mathrm{b} 3}$ & $17.91 \pm 0.680^{\mathrm{b} 3}$ & $16.71 \pm 0.685^{c 2}$ \\
\hline & 1 & $50.88 \pm 0.870^{c 3}$ & $60.04 \pm 2.075^{\mathrm{b} 3}$ & $62.62 \pm 3.395^{\mathrm{a} 2}$ & $62.66 \pm 0.680^{\mathrm{a} 3}$ \\
\hline \multirow{3}{*}{$\begin{array}{l}\text { Water holding } \\
\text { capacity }(\%)\end{array}$} & 10 & $53.28 \pm 3.005^{\mathrm{c} 2}$ & $62.82 \pm 0.495^{\mathrm{b} 2}$ & $63.25 \pm 0.445^{\mathrm{a} 2}$ & $64.17 \pm 3.430^{\mathrm{a} 2}$ \\
\hline & 20 & $57.00 \pm 1.405^{\mathrm{cl}}$ & $66.90 \pm 1.780^{\mathrm{b} 1}$ & $67.96 \pm 0.350^{\mathrm{b} 1}$ & $70.98 \pm 0.535^{\mathrm{a} 1}$ \\
\hline & 1 & $2995 \pm 139^{\mathrm{d} 3}$ & $4770 \pm 126^{c^{3}}$ & $5479 \pm 59 \pm{ }^{b 3}$ & $5798 \pm 134^{\mathrm{a} 3}$ \\
\hline \multirow[t]{2}{*}{ Viscosity (cP) } & 10 & $4926 \pm 320^{\mathrm{d} 2}$ & $5631 \pm 217^{c 2}$ & $6876 \pm 588^{\mathrm{b} 2}$ & $7652 \pm 142^{\mathrm{a} 2}$ \\
\hline & 20 & $5171 \pm 265^{\mathrm{d} 1}$ & $6042 \pm 178^{\mathrm{cl}}$ & $7095 \pm 455^{\mathrm{b} 1}$ & $7947 \pm 267^{\mathrm{al}}$ \\
\hline
\end{tabular}

${ }^{*}$ A: control, B: $0.5 \%$ CF, C: $1 \%$ CF, D: $2 \%$ CF added bio-yogurts. ${ }^{*}$ Different letters in the same line indicate significant differences among the samples depending on CF level and different numbers in the same column indicate significant differences among the samples depending on storage time $(p<0.05)$. 
used as a hygroscopic agent in many foods. Reserches reported that microcrystalline cellulose improving reological and textural properties various food [9] [26] [28]. Syneresis in the samples decreased during storage. This could be due to metbolic activity of yogurt starter cultures, and to decrease in net pressure in protein matrix, which cause to diminish in syneresis [29]. La Torre, Tamime and Muir [30] obtained similar results in set-type yogurt and bio-yogurt.

Bio-yoghurts with CF showed a significantly higher level water holding capacity $(p<0.01)$ than control. As known fiber may act as a stabilizer due to its capacity for binding water [31] [32]. Water holding capacity of the samples increased as the fiber rate increased $(p<0.05)$.

The viscosity of the bio-yogurt samples fortified with $\mathrm{CF}$ was higher than control sample. The increased viscosity of the CF-enriched bio-yogurt seems to be caused by the contribution of insoluble fibers to the increase of total solids [33], affecting the three dimensional conformation of the hydrated biopolymers. Viscosity values significantly increased with increasing the fiber levels. This can be explained by the interactions of the $\mathrm{CF}$ and liquid components of bio-yoghurt. CF, being very hygroscopic, would bind water [9] [26] [28]. Viscosity and water holding capacity of bio-yoghurts increased continuously throughout storage period in a similar way for all the samples $(p<0.01)$.

\subsection{Textural Properties}

Addition of CF into the bio-yoghurts, as well as the storage period, affected the textural properties of the samples $(p<0.01)$. Firmness, cohesiveness, springiness, gumminess and chewiness values of bio-yoghurts increased as CF level increased, but adhesiveness decreased (Table 3). This can be explained by increasing dry matter of bio-yoghurts enriched with CF. Increasing in dry matter caused to firmer and stronger gel. Zisu and Shah [34] reported that cheeses with the lower moisture content showed greater cohesiveness. As with cohesiveness, the relationship between moisture and hardness and their effects on the protein microstructure existed for springiness and are responsible for the loss in the ability of the cheese to recover to its original state [34]. As a result while firmness, cohesiveness, springiness, gumminess and chewiness values are increasing, adhesiveness value reduced in bio-yoghurts. On the other hand, highly water binding capacity of CF may cause to be firmer gel network. Do Espiroto Santo et al. [35] also reported that addition of passion fruit peel powder increased firmness and consistency of skim yoghurt. However, Garcia-Perez et al. [36] found that the addition of orange fiber below $1 \%$ concentration reduce the firmness of skim yoghurt.

All texture parameters (except cohesiveness and springiness) significantly increased during cold storage. It could be related to depending on the decrease in $\mathrm{pH}$, the protein-protein interactions and therefore, slow protein rearrangements in the acid casein gels continue during cold storage [17]. 
Table 3. The changes of textural properties of bio-yogurt enriched cellulose fiber (CF) during storage period ${ }^{* *}$.

\begin{tabular}{|c|c|c|c|c|c|}
\hline Properties & $\begin{array}{l}\text { Day of } \\
\text { Storage }\end{array}$ & $\mathrm{A}^{*}$ & B & $\mathrm{C}$ & $\mathrm{D}$ \\
\hline \multirow{3}{*}{ Firmness } & 1 & $201.26 \pm 9.179^{\mathrm{g} 3}$ & $216.91 \pm 7.139^{f 3}$ & $238.76 \pm 11.981^{\mathrm{e} 3}$ & $251.45 \pm 9.487^{\mathrm{d} 3}$ \\
\hline & 10 & $243.41 \pm 11.80^{\mathrm{e} 2}$ & $247.33 \pm 12.217^{\mathrm{d} 2}$ & $277.19 \pm 12.69^{c 2}$ & $287.21 \pm 10.54^{\mathrm{b} 2}$ \\
\hline & 20 & $274.99 \pm 14.203^{\mathrm{cl}}$ & $293.97 \pm 8.26^{\mathrm{b} 1}$ & $318.04 \pm 11.50^{\mathrm{a} 1}$ & $323.94 \pm 13.46^{\mathrm{a}}$ \\
\hline \multirow{3}{*}{ Adhesiveness } & 1 & $-116.07 \pm 0.946^{\mathrm{h} 3}$ & $-97.76 \pm 0.647^{\mathrm{i} 3}$ & $-94.26 \pm 1.759^{9^{3}}$ & $-92.30 \pm 2.281^{\mathrm{k} 3}$ \\
\hline & 10 & $-142.60 \pm 2.331^{\mathrm{e} 2}$ & $-124.81 \pm 3.108^{\mathrm{f} 2}$ & $-119.62 \pm 1.591^{\mathrm{g} 2}$ & $-111.69 \pm 1.957^{12}$ \\
\hline & 20 & $-213.21 \pm 2.352^{\mathrm{a} 1}$ & $-201.04 \pm 0.765^{\mathrm{b} 1}$ & $-164.82 \pm 1.786^{\mathrm{cl}}$ & $-145.40 \pm 2.712^{\mathrm{d} 1}$ \\
\hline \multirow{3}{*}{ Cohesiveness } & 1 & $0.34 \pm 0.006^{\mathrm{b} 1}$ & $0.35 \pm 0.006^{\mathrm{b} 1}$ & $0.37 \pm 0.033^{\mathrm{a} 1}$ & $0.38 \pm 0.003^{\mathrm{al}}$ \\
\hline & 10 & $0.33 \pm 0.0014^{\mathrm{b} 2}$ & $0.34 \pm 0.001^{\mathrm{b} 2}$ & $0.35 \pm 0.009^{\mathrm{b} 1}$ & $0.36 \pm 0.009^{\mathrm{a} 1}$ \\
\hline & 20 & $0.32 \pm 0.006^{\mathrm{c} 2}$ & $0.34 \pm 0.038^{\mathrm{b} 2}$ & $0.34 \pm 0.001^{\mathrm{b} 2}$ & $0.36 \pm 0.007^{\mathrm{a} 1}$ \\
\hline \multirow{3}{*}{ Springiness } & 1 & $93.64 \pm 0.279^{\mathrm{f} 2}$ & $95.36 \pm 0.449^{\mathrm{d} 2}$ & $96.41 \pm 0.150^{\mathrm{bl}}$ & $96.93 \pm 0.324^{\mathrm{a} 1}$ \\
\hline & 10 & $93.91 \pm 0.692^{\mathrm{e} 2}$ & $96.03 \pm 0.524^{\mathrm{cl}}$ & $96.56 \pm 0.299^{\mathrm{bl}}$ & $96.97 \pm 0.868^{\mathrm{al}}$ \\
\hline & 20 & $92.96 \pm 0.749^{\mathrm{g} 3}$ & $94.01 \pm 0.449^{\mathrm{e} 2}$ & $96.16 \pm 0.197^{\mathrm{b} 3}$ & $96.22 \pm 0.240^{c 3}$ \\
\hline \multirow{3}{*}{ Gumminess } & 1 & $82.85 \pm 1.401^{\mathrm{j} 3}$ & $83.97 \pm 2.315^{\mathrm{i} 3}$ & $84.22 \pm 0.365^{\mathrm{i} 3}$ & $88.59 \pm 2.0^{\mathrm{g}^{3}}$ \\
\hline & 10 & $85.19 \pm 0.697^{12}$ & $87.52 \pm 0.584^{\mathrm{h} 2}$ & $88.82 \pm 1.394^{\mathrm{f} 2}$ & $95.43 \pm 1.035^{\mathrm{d} 2}$ \\
\hline & 20 & $91.83 \pm 0.994^{\mathrm{el}}$ & $102.04 \pm 1.641^{\mathrm{cl}}$ & $105.22 \pm 0.118^{\mathrm{b} 1}$ & $109.82 \pm 0.425^{\mathrm{a} 1}$ \\
\hline \multirow{3}{*}{ Chewiness } & 1 & $69.88 \pm 0.402^{\mathrm{j} 3}$ & $75.72 \pm 1.787^{13}$ & $81.18 \pm 0.832^{\mathrm{g} 3}$ & $88.15 \pm 0.115^{\mathrm{e} 3}$ \\
\hline & 10 & $74.30 \pm 1.099^{\mathrm{i} 2}$ & $79.95 \pm 0.709^{\mathrm{h} 2}$ & $87.69 \pm 1.164^{\mathrm{f} 2}$ & $92.12 \pm 0.406^{\mathrm{c} 2}$ \\
\hline & 20 & $88.49 \pm 1.030^{\mathrm{e} 1}$ & $90.31 \pm 1.136^{\mathrm{d} 1}$ & $95.98 \pm 1.402^{\mathrm{b} 1}$ & $100.51 \pm 1.313^{\mathrm{a} 1}$ \\
\hline
\end{tabular}

${ }^{*} \mathrm{~A}$ : control, B: $0.5 \% \mathrm{CF}, \mathrm{C}: 1 \% \mathrm{CF}, \mathrm{D}: 2 \% \mathrm{CF}$ added bio-yogurts. ${ }^{*}$ Different letters in the same line indicate significant differences among the samples depending on CF level and different numbers in the same column indicate significant differences among the samples depending on storage time $(p<0.05)$.

\subsection{Sensory Evaluations}

The results of organoleptic evaluation indicated that the bio-yogurt enriched with $0.5 \%$ CF received highest scores (Figures 1-3). This could be related to better consistency and acidity of these samples. The higher fiber concentration ( $1 \%$ and $2 \%)$ caused the lower sensory scores. It could be related to insolubility of the CF. All sensory scores of the samples decreased during storage. This could be associated with acidity and flavor of the bio-yoghurts. At the beginning of storage, samples had intensive flavour and low acidity. But, after 20 days they were more acidic, so they had received lower organoleptic scores.

\section{Conclusions}

Addition of CF had significant effects on the physico-chemical, textural, viable bacterial counts and sensory characteristics of bio-yogurt. Whey separation and $\mathrm{pH}$ reduced, while the level of titratable acidity, water holding capacity and viscosity increased in the bio-yogurts supplemented with CF. During the storage, whilst the whey separation and $\mathrm{pH}$ values declined gradually, the titratable acidity water holding capacity and viscosity increased at the same time. 


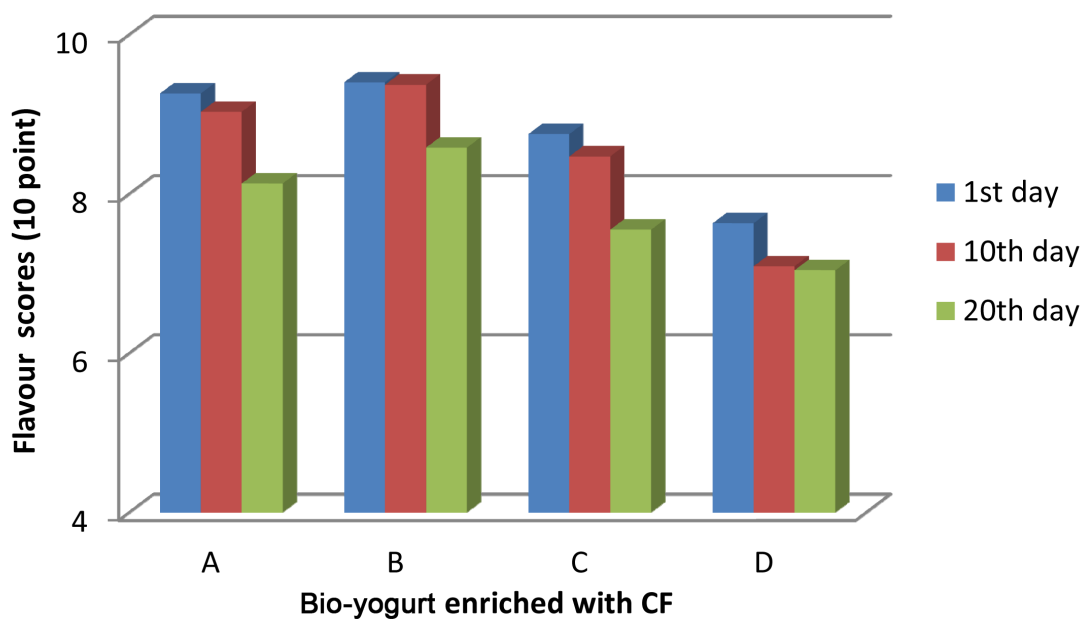

Figure 1. The changes of flavour scores of bio-yogurt ${ }^{\star}$ enriched cellulose fiber (CF) during storage period. ${ }^{*} \mathrm{~A}$ : control, B: $0.5 \% \mathrm{CF}, \mathrm{C}: 1 \% \mathrm{CF}, \mathrm{D}: 2 \% \mathrm{CF}$ added bio-yogurts.

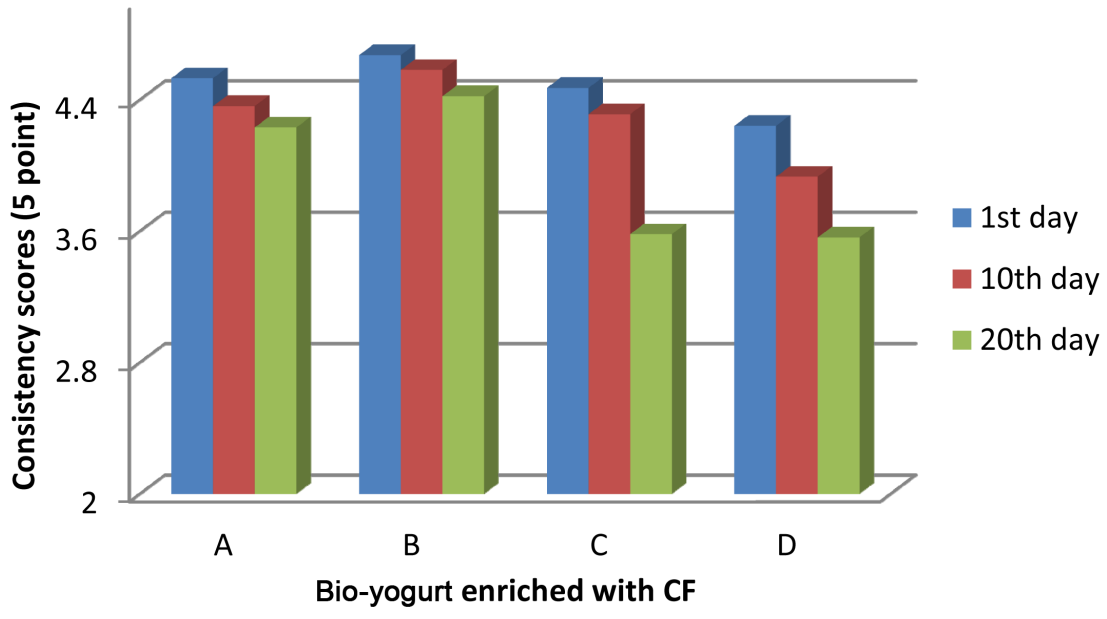

Figure 2. The changes of consistency scores of bio-yogurt ${ }^{\star}$ enriched cellulose fiber (CF) during storage period. ${ }^{\star *}$ A: control, B: $0.5 \% \mathrm{CF}, \mathrm{C}: 1 \% \mathrm{CF}, \mathrm{D}: 2 \% \mathrm{CF}$ added bio-yogurts.

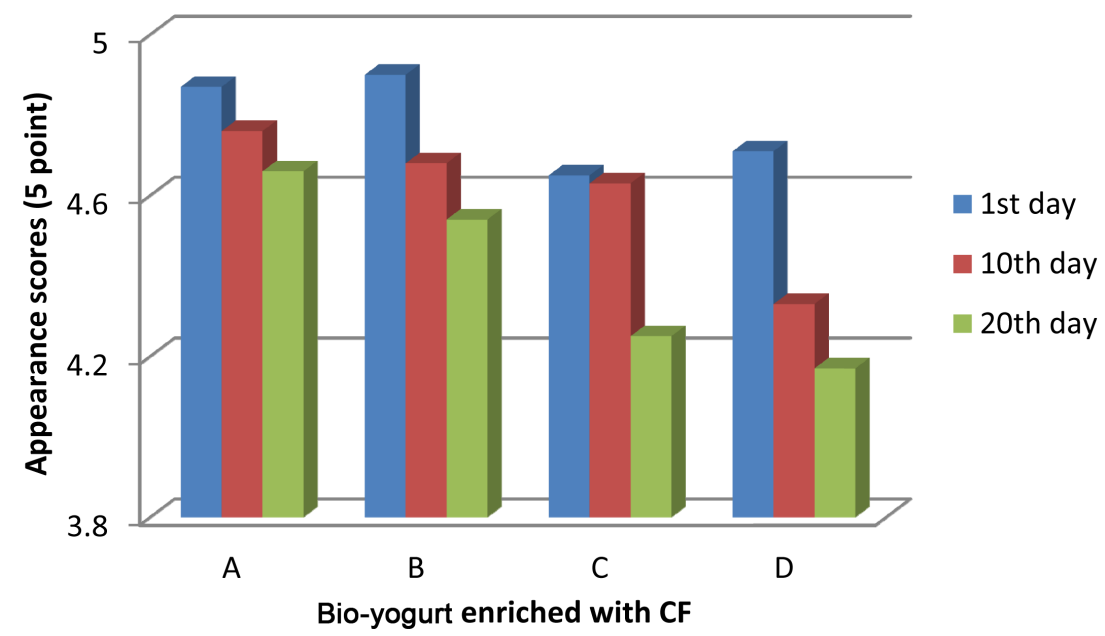

Figure 3. The changes of appearance scores of bio-yogurt* enriched cellulose fiber (CF) during storage period. ${ }^{\star *} \mathrm{~A}$ : control, B: $0.5 \% \mathrm{CF}, \mathrm{C}: 1 \% \mathrm{CF}, \mathrm{D}: 2 \% \mathrm{CF}$ added bio-yogurts. 
The counts of probiotic bacteria were adversely affected by addition of CF. Addition of $\mathrm{CF}$ at a rate of $0.5 \%$ led to an improvement in viability of $L$. acidophilus and Bifidobacterium BB-12. Usage of CF at a rate of $1 \%$ and $2 \%$ had negatively affected the viability of $L$. acidophilus and Bifidobacterium BB-12. On contarory, $S$. thermophilus counts increased with increasing CF level. During the storage, the viable counts of both probiotics and $S$. thermophilus dropped in all samples.

Addition of $\mathrm{CF}$ at a rate of $0.5 \%$ led to an improvement of sensory scores of bio-yogurts. Sensory scores declined with increasing CF level. Consequently, addition of $\mathrm{CF}$ at a rate of $0.5 \%$ could be satisfactorily used to produce bio-yogurt.

\section{References}

[1] Vinderola, C.G. and Reinheimer, J.A. (2000) Enumeration of L. paracasei subsp. casei in the Presence of L. acidophilus, Bifidobacteria and Starter Bacteria in Fermented Dairy Products. International Dairy Journal, 10, 271-275. https://doi.org/10.1016/S0958-6946(00)00045-5

[2] IDF (1992) International Standard 163. General Standard of Identity for Fermented Milks. International Dairy Federation, Brussels.

[3] Klaver, F.A., Kingma, F. and Weerkamp, A.H. (1993) Growth and Survival of Bifidobacteria in Milk. Netherlands Milk and Dairy Journal, 47, 151-164.

[4] Dave, R.I. and Shah, N.P. (1997) Effect of Cysteine on the Viability of Yoghurt and Probiotic Bacteria in Yoghurts Made with Commercial Starter Cultures. International Dairy Journal, 7, 537-545. https://doi.org/10.1016/S0958-6946(97)00053-8

[5] Ravula, R.R. and Shah, N.P. (1998) Effect of Acid Casein Hydrolysate and Cysteine on the Viability of Yogurt and Probiotic Bacteria in Fermented Frozen Dairy Desserts. Australian Journal of Dairy Technology, 53, 175-179.

[6] Lourens-Hattingh, A. and Viljoen, B.C. (2001) Yogurt as Probiotic Carrier Food. International Dairy Journal, 11, 1-17. https://doi.org/10.1016/S0958-6946(01)00036-X

[7] Tomic, N., Dojnov, B., Miocinovic, J., Tomasevic, I., Simigic, N., Djekic, I. and Vujcic, Z. (2017) Enrichment of Yoghurt with Insoluble Dietary Fiber from Triticale-A Sensory Perspective. LWT-Food Science and Technology, 80, 59-66. https://doi.org/10.1016/j.lwt.2017.02.008

[8] Akin, M.S., Goncu, B., Celikel, A. and Akin, M.B. (2017) Usage of Inulin, Lemon and Pea Fibers as Prebiotic for Lactobacillus acidophilus. Litvanya. 4th North and East European Congress on Food, Kaunas, 10-13 September 2017.

[9] Nsor-Atindana, J., Chen, M., Goff, H.D., Zhong, F., Sharif, H.R. and Li, Y. (2017) Functionality and Nutritional Aspects of Microcrystalline Cellulose in Food. Carbohydrate Polymers, 172, 159-174. https://doi.org/10.1016/j.carbpol.2017.04.021

[10] Gidley, M.J. (2013) Hydrocolloids in the Digestive Tract and Related Health Implications. Current Opinion in Colloid \& Interface Science, 18, 371-378. https://doi.org/10.1016/j.cocis.2013.04.003

[11] Paturi, G., Butts, C., Monro, J., Nones, K., Martell, S., Butler, R. and Sutherland, J. (2010) Cecal and Colonic Responses in Rats Fed 5 or 30\% Corn Oil Dietscontaining Either 7.5\% Broccoli Dietary Fiber or Microcrystalline Cellulose. Journal of Agricultural and Food Chemistry, 58, 6510-6515. https://doi.org/10.1021/jf100296m

[12] Tamime, A.Y. and Robinson, R.K. (1999) Yogurt Science and Technology. 2nd Edi- 
tion, Woodhead Publishing Ltd., Cambridge, 619.

[13] Yöney, Z. (1973) Süt ve süt ürünleri analiz yöntemleri. A. Ü. Ziraat Fakültesi Yayınları: 491, A. Ü. Basımevi, Ankara, 182.

[14] AOAC (1990) Official Methods of Analysis. 15th Edition, Association of Official Analytical Chemists, Arlington.

[15] Kessler, H.G. and Kammerlahner, J. (1982) Factors Affecting the Stability of Natural Set Yogurt. In: XXI International Dairy Congress, Vol. 1, U.S.S., Moscow, 283.

[16] Goncu, B., Celikel, A., Güler-Akin, M.B. and Akin, M.S. (2017) Some Properties of Kefir Enriched with Apple and Lemon Fiber. Mljekarstvo, 67, 208-216. https://doi.org/10.15567/mljekarstvo.2017.0305

[17] Ozer, B., Robinson, R.K., Grandison, A.S. and Bell, A.E. (1997) Comparison of Techniques for Measuring the Rheological Properties of Labneh (Concentrated Yoghurt). International Journal of Dairy Technology, 50, 129-133. https://doi.org/10.1111/j.1471-0307.1997.tb01753.x

[18] Damin, M.R., Minowa, E., Alcantara, M.R. and Oliveira, M.N. (2008) Effect of Cold Storage on Culture Viability and Some Rheological Properties of Fermented Milk Prepared with Yoghurt and Probiotic Bacteria. Journal of Texture Studies, 39, 40-55. https://doi.org/10.1111/j.1745-4603.2007.00129.x

[19] Rybka, S. and Kailasaphaty, K. (1996) Media for Enumeration of Yogurt Bacteria. International Dairy Journal, 6, 839-850. https://doi.org/10.1016/0958-6946(96)00017-9

[20] Dave, R.I. and Shah, N.P. (1996) Evaluation of Media for Selective Enumeration of Streptococcus thermophilus, Lactobacillus delbrueckii subsp. bulgaricus, L acidophilus and Bifidobacteria. Journal of Dairy Science, 79, 1529-1536. https://doi.org/10.3168/jds.S0022-0302(96)76513-X

[21] Bodyfelt, F.W., Tobias, J. and Trout, G.M. (1988) The Sensory Evaluation of Dairy Products. An Avi Book Published by Van Nostrand Reinhold, New York, 598.

[22] Düzgüneş, O., Kesici, T., Kavuncu, O. and Gürbüz, F. (1987) Researches and Practice Methods (Statistical Methods II). A. U. Agricultural Faculty Publishes: 1021, Ankara, 381.

[23] Sendra, E., Fayos, P., Lario, Y., Fernandez-Lopez, J., Sayas-Barbera, E. and Perez-Alvarez, J.A. (2008) Incorporation of Citrus Fibers in Fermented Milk Containing Probiotic Bacteria. Food Microbiology, 25, 13-21. https://doi.org/10.1016/j.fm.2007.09.003

[24] Akin, M.S. and Akin, M.B. (2016) Elma Lifi ile Zenginleştirmenin Set Tipi Yoğurtların Bazı Özelliklerine Etkisi. Harran Tarım ve Gıda Bilimleri Dergisi, 20, 94-104. https://doi.org/10.29050/harranziraat.259100

[25] Kalashnikova, I., Bizot, H., Cathala, B. and Capron, I. (2011) New Pickering Emulsionsstabilized by Bacterial Cellulose Nanocrystals. Langmuir, 27, 7471-7479. https://doi.org/10.1021/la200971f

[26] Xu, D., Zhang, J., Cao, Y., Wang, J. and Xiao, J. (2016) Influence of Microcrystalline cellulose on the Microrheological Property and Freeze-Thaw Stability of Soybean Protein Hydrolysate Stabilized Curcumin Emulsion. LWT-Food Scienceand Technology, 66, 590-597. https://doi.org/10.1016/j.lwt.2015.11.002

[27] Guler-Akin, M.B. and Akin, M.S. (2007) Effects of Cysteine and Different Incubation Temperatures on the Microflora, Chemical Composition and Sensory Characteristics of Bio-Yogurt Made from Goat's Milk. Food Chemistry, 100, 788-793. https://doi.org/10.1016/j.foodchem.2005.10.038 
[28] Nawar, G.A.M., Hassan, F.A.M., Ali, E.K., Kassem, J.M. and Mohamed, S.H.S. (2010) Utilization of Microcrystalline Cellulose Prepared from Rice Straw İnmanufacture of Yoghurt. Journal of Americal Science, 6, 226-231.

[29] Akın, N. (1998) İnek ve koyun sütünden üretilen konsantre yoğurdun su tutma kapasitesi indeksinin belirlenmesi. Gıda Mühendisliği Kongre ve Sergisi, Gaziantep, 16-18 Eylül 1998.

[30] La Torre, L., Tamime, A.Y. and Muir, D.D. (2003) Rheology and Sensory Profiling of Set-Type Fermented Milks Made with Different Commercial Probiotic and Yogurt Starter Culture. International Journal of Dairy Technology, 56, 163-170. https://doi.org/10.1046/j.1471-0307.2003.00098.x

[31] Elleuch, M., Bedigian, D., Roiseux, O., Besbes, S., Blecker, C. and Attia, H. (2011) Dietary Fiber and Fiber-Rich By-Products of Food Processing: Characterisation, Technological Functionality and Commercial Applications: A Review. Food Chemistry, 124, 411-421. https://doi.org/10.1016/j.foodchem.2010.06.077

[32] Mudgil, D. and Barak, S. (2013) Composition, Properties and Health Benefits of Indigestible Carbohydrate Polymers as Dietary Fiber: A Review. International Journal of Biological Macromolecules, 61, 1-6. https://doi.org/10.1016/j.ijbiomac.2013.06.044

[33] Soukoulis, C., Lebesi, D. and Tzia, C. (2009) Enrichment of Ice Cream with Dietary Fiber: Effects on Rheological Properties, Ice Crystallisation and Glass Transition Phenomena. Food Chemistry, 115, 665-671. https://doi.org/10.1016/j.foodchem.2008.12.070

[34] Zisu, B. and Shah, N.P. (2004) Textural and Functional Changes in Low Fat Mozzarella Cheeses in Relation to Proteolysis and Microstructure as İnfluenced by the Use of Fat Replacers, Pre-Acidifi Cation and EPS Starter. International Dairy Journal, 15, 957-972. https://doi.org/10.1016/j.idairyj.2004.09.014

[35] Do Espiroto Santo, A.P., Perego, P., Converti, A. and Oliveira, M.N. (2012) Influence of Milk Type and Addition of Passion Fruit Peel Powder on Fermentation Kinetics, Texture Profile and Bacterial Viability in Probiotic Yoghurts. LWT-Food Science and Technology, 47, 393-399. https://doi.org/10.1016/j.lwt.2012.01.038

[36] Garcia-Perez, F.J., Sendra, E., Lario, Y., Fernandez-Lopez, J., Sayas-Barbera, E. and Perez-Alvarez, J.A. (2006) Rheology of Orange Fiber Enriched Yogurt. Milchwissenschaft-Milk Science International, 61, 55-59. 